This work is licensed under a Creative Commons Attribution 4.0 International License.

\title{
RIJEČKI ODVJETNIK, ILIRAC I SLAVENOFIL DR. VATROSLAV VINKO MEDANIĆ
}

dr. sc. Irvin Lukežić, Filozofski fakultet, ilukezic2@ffri.hr, Rijeka

izvorni znanstveni članak

UDK 930.85(497.5 Rijeka)"18“

347.965-05 Medanić, V. V.

rukopis primljen: 21. 2. 2018.; prihvaćen za tisak: 29. 3. 2018.

Tema ovoga priloga vezana je za Rijeku u doba neoapsolutizma, kada počinje djelovati Narodna čitaonica riečka, za čije su osnivanje posebno zaslužan dr. Ignac (Vatroslav) Vinko Medanić (1805.-1856.), istaknuti riječki odvjetnik, posjednik i brodovlasnik, patricijski vijećnik Bakra i Rijeke. Riječ o neobično značajnom riječkom građ̄aninu svoga vremena, danas nažalost zaboravljenom, koji se istaknuo na mnogim područjima. Bio je znanac hrvatskoga pravopisnoga reformatora Josipa Završnika, slovačkoga preporoditelja Jana Kollára, vođe ilirskoga pokreta Ljudevita Gaja, bana Josipa Jelačića Bužimskoga, hrvatskoga polihistora Ivana Kukuljevića Sakcinskog i drugih znamenitih osoba svoga vremena. Bio je prvi potpredsjednik Narodne čitaonice riečke i glavni vladin povjerenik za osnivanje Gospodarske komore u Rijeci. U prilogu se govori o najvažnijim o biografskim pojedinostima i značajkama njegova javnoga djelovanja, posebno na području narodne prosvjete i kulture.

Ključne riječi: Rijeka; 19. stoljeće; hrvatska kultura; Medanić; ilirizam; slavenstvo

\section{Uvod}

Tema ovoga članka vezana je za Rijeku u doba neoapsolutizma što je uslijedilo odmah nakon četrdesetosmaških nemira i buna, kada su ljudi diljem Hrvatske i Europe bili ispunjeni dubokom vjerom u nužnost velikih promjena i stvaranje novoga, pravednijega svijeta slobode i pravde, posebno 
u smislu postupne afirmacije i emancipacije malih naroda, koji su dotada bili podređeni većim i kulturno dominantnijim narodima. Međutim, uskoro je uslijedilo hladno otrežnjenje i prizemljenje, jer su reakcionarni režimi vrlo brzo uspostavili kontrolu nad situacijom, kako bi još čvršće konsolidirali svoju vlast. Nakon što se Habsburška Monarhija, uvelike uzdrmana ratovima i revolucijama, ponovno uspjela pribrati, uslijedilo je razdoblje nove birokratizacije društva i stvaranje države u kojoj je uvedena stroga cenzura, zabranjeno svako političko djelovanje i ukinute sve demokratske građanske slobode, te se u zemljama i provincijama izvan njemačkoga kulturnoga kruga koje su bile sastavnice Carevine stala provoditi germanizacija u školstvu, upravi i javnom životu. ${ }^{1}$

U Rijeci i čitavom Hrvatskom primorju bilo je puno Bachovih husara², o kojima svjedoči Janez Trdina u svojim poznatim memoarima, koji su revnosno progonili svakoga onoga tko bi se drznuo javno govoriti hrvatskim jezikom ili slobodno izražavati svoje rodoljublje. Sveukupni javni život odvijao se prema naređenjima svemoćne austrijske birokracije. Posebno je teška situacija bila u školama i obrazovnim ustanovama. Godine 1853. Fran Kurelac, profesor hrvatskoga jezika na riječkoj gimnaziji, bio je optužen radi svoga govora $O$ preporodu knjige slavenske na jugu ${ }^{3}$, te bio otpušten iz državne službe. Unatoč tome, početkom neoapsolutizma ovdje počinje djelovati Narodna čitaonica riečka ${ }^{4}$, za čije je osnivanje posebno značajan ugledni riječki odvjetnik dr. Vatroslav Vinko Medanić, čijom ćemo se biografijom ovdje pozabaviti.

\section{Podrijetlo i obitelj}

Dr. Ignac (Vatroslav) Vinko Medanić (1805.-1856.), istaknuti riječki je odvjetnik, posjednik i brodovlasnik, patricijski vijećnik Bakra i Rijeke, koji se istaknuo na mnogim područjima. Potjecao je iz ugledne i imućne obitelji pomoraca podrijetlom iz Kostrene Sv. Barbare. Majka mu se zvala Stanislava.

1 M. Gross, Počeci moderne Hrvatske: neoapsolutizam u civilnoj Hrvatskoj i Slavoniji 18501860, Delo, Ljubljana; Globus, Zagreb; Centar za povijesne znanosti sveučilišta u Zagrebu, Zagreb 1985.

2 Naziv „Bachovi husari” nastao je izvorno u Mađarskoj, a vrlo se brzo proširio i u susjednu Hrvatsku. Odnosio se na austrijske državne činovnike koji su nosili zelene odore nalik husarskima. J. Trdina, Bachovi husari i ilirci, GZH, Zagreb 1983.

3 F. Kurelac, O preporodu knjige slovinske na jugu, Trst 1853.

4 Spomen-knjiga Narodne Čitaonice Riečke, Sušak 1901. 
Njegov otac Grgur Medanić mlađi (1775.-1833.) bio je bogati riječki kapetan duge plovidbe, posjednik i brodovlasnik, rodom iz Bakra, koji je desetljećima obnašao čast konzularnoga agenta i vicekonzula Kraljevine Sardinije u Rijeci. Ovaj console sardo u mladosti je bio pomorski kapetan duge plovidbe. Stekavši znatan imetak, posvetio se trgovini, nastanio u Rijeci i postao brodovlasnik. Za vrijeme francuske vladavine bio je načelnik (maire) Kostrene i član riječke masonske lože, kojoj je tada pripadao i glasoviti veletrgovac Andrija Ljudevit Adamić (Adamich). Godine 1823. sagradio je Grgur Medanić na Sušaku jedrenjak nosivosti 223 tone koji je nazvan prema riječkome guverneru Ürmenyju, a 1833. imenovan je riječkim patricijskim vijećnikom. Bio je suvlasnik spomenutoga brigantina Úrmeny, brigantina Lampo, i škuner-brika Opritz, te je posjedovao kuću na Fiumari br. 409, kuću u Kostreni, kuću s posjedom na Sušaku i kuću u Anconi. Godine 1830. postaje vlasnikom Pisanellova mlina, kupivši ga na dražbi. Njegovi su nasljednici, iz braka sa suprugom Stankom, bili dioničari Società Patriotica Fiumana (1834.) i posjedovali skladište žita u Contrada del ponte (1841.). ${ }^{5}$

Ignac Vinko Medanić nije se želio posvetiti pomorstvu, poput svoga oca i braće Tome i Antuna, već je odlučio krenuti drugim stopama. Godine 1823. upisao se „in facultate philosophica” Sveučilišta u Padovi. U studentskoj matrikuli bilo je navedeno da u to vrijeme ima osamnaest godina i da je „natus Fiume littorale Hungarico”. ${ }^{6}$ Nakon završenih pravnih studija stječe doktorat te svoju plodnu karijeru započinje kao pripravnik (praticante di concetto) kod Carskoga i Kraljevskog Fiškalata u Trstu. ${ }^{7}$ Nakon povratka u Rijeku, kao zaprisegnuti odvjetnik (causarum advocatus), obnašao je funkciju honorarnoga gradskog fiškala. ${ }^{8}$

Godine 1834. oženio se riječkom patricijkom Annom, kćeri Frana Ksavera de Benzonija. ${ }^{9}$ Te iste godine spominje se, zajedno sa svojim nećakom Eduardom Medanićem Tominim, koji je bio rođen na Malti, kao

\footnotetext{
5 I. Lukežić, Povijest riječkih konzulata, Adamić, Rijeka, 2004, str. 147.

6 Fontes rerum hungaricarum. Magyar törtenélmi fórrasok: MATRICULA ED AETA HUNGARORUM IN UNIVERSITATIBUS ITALIAE STUDENTUM, vol. I, PADOVA 12641864, Budapest 1915, str. 138.

7 Scematismo dell 'imperiale Regio Litorale austriaco-illirico, Trieste 1831, str. 10.

8 Scematsmo Del Littorale Ungarico, Fiume 1838, str. 97. i 133.

9 Riječka patricijska obitelj Benzoni potjecala je iz grada Bergama u sjevernoj Italiji. U Rijeku se doselila tijekom sedamnaestoga stoljeća. Njeni su članovi bili imućni trgovci i ugledni građani. Njihova obiteljska palača, podignuta u baroknom stilu, nalazila se odmah
} 
suvlasnik brigantina Ürmeny, koji je bio porinut u more u Rijeci 1823. godine. ${ }^{10}$ Kao fiscalis publicus civitatis Buccarensis, Ignac Vicko Medanić sudjelovao je 1834. kao službeni predstavnik Bakra na procjeni sušačke Brajde, čija je vrijednost bila procijenjena na 20.641 forintu i 40 krajcara. ${ }^{11}$ Prema podacima iz sudskih izvora, odvjetnik Medanić 1835. godine nastanio se na Sušaku ('prese stabile domicilio a Sussak'), gdje ce sa svojom obitelji živjeti do smrti.

Nakon smrti svoje prve supruge 1843. oženio se Vinko Medanić Frankom (Francescom) de Zaccaria, koja je bila potomak ugledne patricijske obitelji. Tom prigodom prigodne stihove na talijanskome posvetio im je riječki liječnik dr. Giovanni Spagnuolo, glavni urednik dnevnika Eco del Litorale Ungarico. ${ }^{12}$ Za razliku od Benzonijevih, koji su bili stari i vrlo utjecajni patricijski rod, Zaccarije su pripadali novijem građanskom sloju Rijeke koji se zahvaljujući svojem bogatstvu tek početkom devetnaestoga stoljeća uspio domoći povlaštenoga patricijskog statusa. Mladenkin otac, Francesco de Zaccaria Adamov, koji bijaše podrijetlom iz Grobnika, bio je sin riječkoga odvjetnika, patricijski vijećnik i općinski činovnik. Njegov otac bio je u doba francuske vladavine riječki načelnik (maire). Više od četiri desetljeća službovao je Francesco Zaccaria u riječkome magistratu kao registrator i otpravnik općinskih spisa. Bio je član riječkoga društva Casino patriottico od njegova osnutka 1848. godine. ${ }^{13}$ Franceschina majka Marija bila je kći riječkoga građanina Domenica Comissa, trgovca vunenim tkaninama i sitnom robom na veliko i malo.

Dr. Ignac Vinko Medanić umro je iznenada u Rijeci 22. srpnja 1856. godine, od kapi, u pedeset i prvoj godini života. Početkom kolovoza te godine Narodne novine ovako prenose vijest o njegovoj smrti: „Uprav sada dobismo iz Rieke žalostnu viest da je tamo umro vriedni domoljub dr.

do crkve Sv. Vida u Starom gradu. Iz te obitelji potekao je i senjsko-modruški biskup Ivan Antun Benzoni.

10 Državni arhiv u Rijeci, PR-1, kut. 326.

11 D. Klen, Gospodarske prilike u Rijeci od 1813. do 1848. do ponovne austrijske okupacije do Bunjevčeva zauzeća, u: Rad JAZU, knj. 417, Zagreb 1986, str. 122.

12 Stihovi su bili objavljeni u tiskari braće Karletzky 1843. godine kao letak pod naslovom Ad Ignazio Medanich quando sacramento di coniugale fede solemente proferiva a Francesca Zaccaria giovane che il terzo lustro appena ha fecco nobile ingenua virtuosa a tutti cara per la bontà del cuore per la dolcezza dei modi $G$. dott. S. quale arra di veri e saltava questi versi dedicano, Fiume 1843. Tipografia fratelli Karletzky.

13 I. Lukežić, Grobnički biografski leksikon, Libellus, Rijeka-Crikvenica 1994, str. 250. 
Vinko Me danić, poznat kao revni podupiratelj domaće književnosti, kao uznešeni promicatelj svega, što je dobro, krasno i obćekoristno, te kao najbolji otac i suprug."14

Iz braka Ignaca Vinka Medanića i Franke rođ. Zaccaria potekli su sinovi Romuald, Delimir i Dragutin te kćeri Jurjinka, Dioniza i Bogumila. Medanićev sin Delimir bio je kapetan duge plovidbe, a Romuald pravnik i sudac. Delimirov sin, dr. Bruno Medanić, bio je ugledni riječki liječnik i predsjednik društva Akademija. Medanićeva kći Ifigenija bila je supruga riječkoga zlatara, bankara i brodovlasnika Giovannija Corosscza, zvanog Zanetto, jednoga od najbogatijih Riječana svoga vremena, koji je za razliku od svoga tasta, velikoga hrvatskog domoljuba, bio mađarofil. ${ }^{15}$ Corossacz je u čast svoje žene jedan svoj jedrenjak duge plovidbe nazvao - bark Ifigenia. ${ }^{16}$ Ifigenija ud. Corossacz rođ. Medanić umrla je 1902. godine u Fužinama. U nekrologu se veli da je bila „stimata e onorata, cuor generoso e di sentimenti filantropici". ${ }^{17}$ Obiteljske portete Vinka Medanića četrdesetih godina izradio je poznati riječki slikar Franjo Colombo. Oni se danas nalaze u Pomorskom i povijesnom muzeju Hrvatskoga primorja.

\section{Prijateljstvo s Janom Kollárom i Ljudevitom Gajem}

U Medanićevu životu posebno će mjesto imati oduševljenje za slavenstvo i snažno hrvatsko domoljublje zahvaljujući kome je zarana postao poznat i izvan svoga primorskog zavičaja. Kao i svaki iskreni ilirac, odnosno domorodac toga vremena, zanosio se idejom slavenske uzajamnosti. Posebno je volio i cijenio domaću književnost, koju je ne samo redovito pratio kao pretplatnik raznih časopisa, nego i zdušno podupirao. Medanić je, primjerice, bio jedan od šesnaest riječkih pretplatnika preporodnoga lista Zora dalmatinska koja je izlazila u Zadru pod uredništvom dr. Ante Kuzmanića te jedan od riječkih pretplatnika zadarskoga lista Pravdonoša. ${ }^{18}$

Godine 1841. Rijeku je posjetio znameniti češki i slovački književnik, preporoditelj Jan Kollár (1793.-1852.), veliki slavenski ideolog i promicatelj

14 Narodne novine (Zagreb), br. 183, 8. kolovoza 1856. Neuredovni dio. Austrianska carevina. Zagreb, 8. kolovoza.

15 I. Lukežić, Riječke glose, ICR, Rijeka 2004, str. 102-3.

16 R. F. Barbalić - I. Marendić, Onput kad smo partili, MH, Rijeka 2004, str. 19-20.

17 La Voce del popolo (Rijeka), 1902. Ifigenia ved. Corossacz nata Medanich (nekrolog).

18 I. Lukežić, Ogledalo bašćinsko, ICR, Rijeka, 2006, str. 235. 
slavenske uzajamnosti, u društvu svoga peštanskog znanca Antonína Doležálka. Tom ga je prigodom Medanić velikodušno dočekao i ugostio u svojoj kući u Rijeci. O tome Kollár u svome putopisu vrlo živopisno i opširno izvještava:

„Ovdašnji Slaven, gospodin V. J. Medanić, odvjetnik i patricij riječki, ne samo da nas je ugostio u svom domu nego nam je bio $i$ vodič po gradu i njegovoj okolici. Ovdje smo po prvi put jeli talijanska jela, kao npr. palentu, kornjače, morske rakove i ribe. $O$ razvikanoj palenti ja sam do tada imao tko zna kakve sve ne predodžbe; ali tek što sam je spazio i okusio, rekao sam: ' $\mathrm{K}$ a ša mati naša a palenta njena kći!' I stvarno je tako, palenta (usp. puls, pultes) nije ništa drugo nego staroslavenska kaša, prvotno narodno jelo u Slavena, slaveno-venetski ostatak u Italiji. / Pred kućom gosp. Medanića stoji visoki kameni stup na vrhu kojega se vijori zastava (njem. Flabbe ${ }^{19}$, šved. Flagga, hol. vlagghe); u sredini je uklesan lik Sv. Vida s modelom grada u ruci a odmah iznad nalazi se ovaj natpis: / Numine sub nostro tute requiescite gentes, / Arbitri vestri quicquid habetis erit. /."20

U to vrijeme taj se kameni stup (tzv. standarac) još nalazio na svom prvotnome mjestu, nasuprot gradskim vratima kod Gradskoga tornja, na današnjem Koblerovom trgu. Na temelju toga možemo zaključiti da se i Medanićeva kuća nalazila na tome gradskom trgu. Latinski natpis na kamenome stupu, za koji Kollár pogrešno navodi da se nalazi ispod, a ne iznad lika gradskoga zaštitnika sv. Vida, u prijevodu na hrvatski glasi: „Pod zaštitom našom mirno počivajte građani, / Odluka vaša bit će o svemu što je vaše.”

Potom Kollár nastavlja:

„U gradu se među dvjema kućama još vide ostaci nadsvođenih rimskih vrata (Arco Romano); to su zapravo kameni blokovi koji su, kako izgleda, spojeni bez maltera. Na brdu Kalvarija tužno izgledaju ruševine onoga zida koji je rimsku carevinu dijelio na istočnu i zapadnu; zid se proteže čak prema Grobniku i dalje do Kranjske. U Rijeci slavenski jezik već mora borbu voditi sa svojim talijanskim protivnikom; sva su okolna sela doduše slavenoilirska a i u Rijeci prosti puk i neki vatreniji rodoljubi govore našim jezikom;

19 Ovo je pogrešno napisano, treba stajati Flagge, op. I. L.

20 Rijeka 1841. iz pera Jana Kollára, Dometi, god. 22 (1989), br. 4, str. 286. 
ali svugdje u takozvanim prosvijećenim kućama i uredima odzvanja talijanski jezik. Pusti pijevca na grede, on će i na pante. Ovdje su doduše i slavenoilirske veletrgovačke $i$ brodovlasničke obitelji: Benetić, Cirković, Kozulić, Milašović, Vičulić i druge, nažalost djeca u njihovim domovima već talijanski brbljaju. U crkvi Sv. Vida svake se nedjelje hrvatski propovijeda i pjeva. Srpska crkva, kojoj je svećenik gosp. Jovetić, ima samo 52 duše: ovaj nam se čovjek puno žalio zbog opadanja ovdašnjeg našeg jezika i stanovništva. $U$ guvernerovoj palači napisana su na ploči imena svih sudaca, bilo ih je dvanaest a šestorica su od njih imala slavenska imena. Tamo su $i$ slike svih guvernera kojih je od 1777. god. bilo sedam. Posjetili smo i pučku školu u kojoj su dvije učiteljice djecu učile samo na talijanskom jeziku. 'Zašto pak ovdje nije uveden slavenski jezik?' Gospodin Medanić mi je na to odgovorio: 'Bile su navodno dugo o tom svade među građanima, izgleda međutim da se u to umiješala gradska vlast i tražila uvođenje mađarskog jezika u ovu školu. Da bi građani to izbjegli, radije su se odlučili za talijanske učiteljice.' 'Tako se zapravo od kiše niste sklonili pod strehu nego samo pod oluk', odgovorio sam. 'To će se sve s vremenom popraviti i nadoknaditi', rekao je naš prijatelj. Na to sam ja dodao: 'Što je jednom $k$ srcu priraslo, naročito u mladosti, povuci kako hoćeš, čvrsto se drži i barem nekakav trag u duši ostavlja.' - I o narodu i jeziku vrijedi ova izreka: Kad se jezik potire, narod se zatire."21

Nakon kratkoga govora o riječkim crkvama, slijedi posebno zanimljiv dio Kollárova putopisa: „Odmah po dolasku u Rijeku požurili smo more pozdraviti na poznatoj paladi (valjda od palus) ili lukobranu koji daleko u more zalazi a gdje brodovi pristaju radi utovara i istovara. Ovdje smo ugledali dvije mlade Slovenke tako lijepe da su svi nazočni promatrali više njih nego brodove i more. Bile su u narodnoj odjeći, valjda sestre, jedna ljepša od druge. Ovdje sam shvatio istinitost onih narodnih izreka od kojih jedna veli: 'Od nekdaj Ljubljanke so lepe slovele' a druga 'Nema puncu nad Krajnicu'. Kad su ove mladice spazile da ih mnoge oči motre, šmugnule su u grad kao košute u šumu. / Nebo je bilo posuto blistavim zvijezdama a mi smo skoro do pola noći šetali gradskim ulicama i morskom obalom uz koju se je ljuljalo mnoštvo osvijetljenih

21 Rijeka 1841. iz pera Jana Kollára, Dometi, god. 22 (1989), br. 4, str. 287. 
ribarskih čamaca, zvanih ribarice. Otprilike oko 11 sati začu se s jedne ribarice zvonka ali tužna pjesma dvojice ribara: / 'Čudila se Lika i Krbava, / Što govori Bugarine Sava, / Kudi pleme Frankopanovića / I viteza bana Zrinovića.' / 'Mili Bože', rekoh ja s čuđenjem, 'pa ova je pjesma od Kačića!' 'Dapače', reče gosp. Medanić, 'to nije ništa novo ni čudno: naš narod a većinom ribari s otoka Krka sve te pjesme znaju i pjevaju, naročito one koje se odnose na njihova nezaboravnog gospodara i dobročinitelja Frankopana i njegovu obitelj."'22

Na Medanićevu je osobnu pismenu preporuku Jan Kollár tijekom svoga boravka u Italiji te iste 1841. godine u Padovi posjetio Riječanina Josipa Završnika, „vatrenog Slavena”, erudita, poliglota, hrvatskoga pravopisnog reformatora i prethodnika narodnoga preporoda, koji je svoju bogatu knjižnicu želio ostaviti svome rodnom gradu za osnivanje jedne velike slavenske čitaonice i knjižnice. ${ }^{23}$ Možemo pretpostaviti da je Medanić mogao upoznati svoga sugrađanina Završnika još tijekom svoga studija u tom gradu. Valja spomenuti da je Jan Kollár u tajništvo zagrebačke ilirske čitaonice 1842. godine položio jedan dukat za podizanje spomenika na Grobničkom polju. ${ }^{24}$

Neobično je važno podsjetiti da je početkom četrdesetih godina upravo Ignac Vinko Medanić kao gostoljubivi domaćin dočekao i vođu ilirskoga pokreta Ljudevita Gaja prilikom njegova prvog posjeta Rijeci te ga je potom pratio na putovanju do Opatije. ${ }^{25}$ Bilo je to početkom srpnja 1841. godine, prigodom Gajeva povratka iz Dalmacije i Dubrovnika, gdje su ga dočekali poput Mesije. Iz Dubrovnika je otplovio parobrodom Conte Mitrowsky u Split, gdje se kratko zadržao, a potom preko Zadra doputovao u Rijeku, a odatle je 7. srpnja stigao u Karlovac, gdje ga je ugostio njegov prijatelj Antun Vakanović. ${ }^{26}$

Ovaj kratki riječki susret s vođom narodnoga preporoda nedvojbeno je utjecao na to da su za Medanića kao gorljiva hrvatskoga domoljuba svakako morali znati već tada i u Zagrebu, te su ga stoga posebno mogli cijeniti oni koji su bili pristaše ilirskoga pokreta.

Zanimljivo je podsjetiti da se Ljudevit Gaj, tada dvadesetogodišnjak, upoznao sa šesnaest godina starijim Janom Kollárom još početkom 1830. godine u Pešti, i to je poznanstvo bilo od presudnoga značaja za razvitak

22 Rijeka 1841. iz pera Jana Kollára, Dometi, god. 22 (1989), br. 4, str. 288.

23 I. Lukežić, Ogledalo bašćinsko, nav. dj., str. 56.

24 Ilirske Narodne novine (Zagreb), VIII, br. 78, 28. rujna 1842. Horvatska i Slavonia.

25 I. Lukežić, Riječki kvartet, Biblioteka Fluminensia, FF, Rijeka 2008, str. 24.

26 J. Horvat, Ljudevit Gaj, SNL, Zagreb 1975, str. 182. 
njegove ideje slavenstva, bila je pokrenuta misao slavenskoga jedinstva kao cilj slavenskih nacionalizama u Austriji, pretvarajući se iz apstraktnosti u poltičku zbilju, nabijenu dinamikom. Dok je Gaj boravio u Pešti, Kollár mu je bio mentor, glavni savjetnik. Saobraćanje s Kollárom dalo je zamah Gajevim zanosima koji u odlučnom trenu dobivaju snagu mesijanstva. Slavenofilstvo postaje za nj ekstaza, snovi o budućnosti Slavena realni ciljevi. Vjeru u svoje vizije prenosi Gaj na druge, tako i postaje njihov kolovođa. Kurelac je rekao da su njemu i njegovim drugovima Gajeve riječi medom mirisale. ${ }^{27}$

\section{Javna, gospodarska, kulturna i politička djelatnost}

Pripadao je Medanić tijekom četrdesetih godina grupi uglednih riječkih građana koji su se zalagali za izgradnju željeznice Sisak - Karlovac - Rijeka (s Antonom Matešićem, Josipom Bakarčićem i Gašparom Matkovićem). U studenome 1843. sudjeluje kao dioničar u osnivanju Društva za izvedbu prethodnih radova za željezničku prugu Vukovar - Rijeka (Društvo za izvedbu prethodnih radova za željezničku prugu Vukovar-Rijeka). U tu je svrhu otkupio ukupno deset dionica vrijednih 500 forinta i postao jednim od upravitelja društva. ${ }^{28} \mathrm{U}$ to doba vrlo je često radi svojih poslova odlazio u Austriju. Krajem kolovoza 1844. godine kao „Advokat und Besitzer” putovao je iz Beča preko Ljubljane u Rijeku. ${ }^{29}$ Potkraj listopada iste godine opet je iz Rijeke preko Ljubljane putovao u Beč. ${ }^{30} \mathrm{U}$ srpnju 1845. godine zajedno s Bartolom Zmajićem, tadašnjim gubernijskim koncipistom, putovao je iz Graza preko Ljubljane u Rijeku. ${ }^{31}$ Prema dnevniku grofa Istvana Széchenyja, koji je u to vrijeme posjetio Rijeku, proizlazi da su ga 16. lipnja 1845. posjetili upravo Zmajić i Medanić te im je tom prigodom savjetovao kako bi trebalo djelovati u tadašnjoj političkoj opoziciji. ${ }^{32}$

Dana 18. veljače 1845. godine sklopljen je u Rijeci formalni pismeni društveni ugovor o osnivanju društva Società per la strada ferrata VukovarFiumana. Za direktore društva imenovani su Pavao Scarpa, dr. Ignac Vinko

\footnotetext{
27 Isto, str. 52. i 58.

28 B. Stulli, Prijedlozi i projekti željezničkih pruga u Hrvatskoj 1825-1863, knj. I., Institut za hrvatsku povijest, Zagreb 1975, str. 219. i 431.

29 Laibacher Zeitung (Ljubljana), br. 69, 27. kolovoza 1844.

30 Laibacher Zeitung (Ljubljana), br. 85, 22. listopada 1844.

31 Laibacher Zeitung (Ljugljana), br. 55, 12. srpnja 1845.

32 Cs. Gy. Kiss, Mađarski velikani u Rijeci i Kvarneru, Novi Kamov, X /2010, sv. 37. br. 4, 38-40.
} 
Medanić te Smith i Meynier. Društvo je imalo predviđenu glavnicu od 16 milijuna forinta, pa je zainteresirane pozivalo na upis. Društvo je, 8. svibnja 1845. godine, zatražilo od Ugarskoga namjesničkoga vijeća koncesiju za gradnju pruge Vukovar-Brod na Kupi. ${ }^{33}$

Godine 1845. dr. Ignac Vinko Medanić bio je član posebne komisije koja se bavila radovima na riječkim lučkim uređajima, a predsjedavao joj je Stjepan de Privitzer, predsjednik Mjembeno-trgovačkoga suda u Rijeci. „Komisija je zaključila da bi Rječinu očišćenu, odnosno izdubenu do dubine od 8 stopa, trebalo osposobiti za luku za kabotažne brodove. Za brodove duge plovidbe trebalo je po prijedlogu komisije izraditi luku u produženju gata pred ribarnicom tako da se taj gat zaokrene prema zapadu, čime bi se dobila zatvorena luka spram južnih vjetrova i valova. Protiv tog prijedloga izjasnio se jedino član komisije dr. V. I. Medanich. Medanich je u zapisniku komisije dao zabilježiti svoje odvojeno mišljenje. Po njemu je za riječku trgovinu bila dovoljna upotreba Rječine kao luke pošto bi se njen tok skrenuo kanalom preko Brajde, a njeno bivše korito uredilo kao luka." ${ }^{34}$

Vinko Medanić nedvojbeno jer pripadao krugu naprednih i svjesnih primorskih domorodaca, te je kao brodovlasnik na svojim jedrenjacima rado isticao hrvatske simbole, koji su se u ono vrijeme povezivali sa ilirskim imenom, upravo kao što su i imena takvih brodova bila tako birana da jasno pokazuju svoju hrvatsku domoljubnu orijentaciju. Svakako nije slučajno ni to da su i njegovi poslovni partneri, s kojima je ulagao zajednički kapital u gradnju brodova, bili izrazito nacionalno opredijeljeni. Koncem rujna 1846. godine Gajeve Narodne novine donose vijest koja ovakvu tvrdnju jasno i nedvojbeno dokazuje:

„Dana 12. rujna porinuo se je u more u bakarskom škveru Sušaku gorostasan brod vlastitost Vatroslava Medanića, Josipa Bakarčića i Antuna Kopajtića. Brod ovaj imenovan je ilirskim Franica narešenoj i na prednjoj strani ili provi sliku ima jedne ilirke u surki, a na zadnjoj ili kérmi u velikom formatu izrezan vás gérb Danice naše, $s$ nadpisom 'Sloga'. - Velepan biaše prizor vidéti, kako gorostas ovaj duboko u more poséran. Reko bi bio Franicu će talasi sa slogom skupa progutati, ali eto brod, premda iz malih komadićah sagradjen,

33 D. Klen, Gospodarske prilike u Rijeci od 1813. do 1848. od ponovne austrijske okupacije do Bunjevčeva zauzeća, Rad JAZU, knj. 417, Zagreb 1986, str. 104.

34 D. Klen, Gospodarske prilike u Rijeci od 1813. do 1848. od ponovne austrijske okupacije do Bunjevčeva zauzeća, Rad JAZU, knj. 417, Zagreb 1986, str. 127. 
nadvlada i raskoli more, i put sebi stvori, i tako svakoj morskoj sili pérkositi mogu; nije bo zapréke, koja se slogom preobladati nebi mogla. - Franica će dakle po sinjem moru, po dalekih stranah světa slogu našu raznositi, koje u nas žalibože još neima!’35

Nava Franica, nosivosti 571 tonu, bila je zajedničko vlasništvo bakarskoga kapetana Antona Kopajtića Tominog, riječkoga odvjetnika i bakarskoga patricija dr. Ignaca (Vatroslava) Medanića i riječkoga veletrgovca Josipa Bakarčića Joška, koji su bili poznati hrvatski rodoljubi. Bakarčić i Medanić posjedovali po devet karata, dok je Kopajtić imao udio u vlasništvu od šest karata. ${ }^{36}$

Simbolika „ilirske surke” i grb „Danice”, kao ime jedrenjaka Franica, više nego jasno dokazuju izrazito domljubnu tendenciju ovih primorskih brodovlasnika. Ovo potvrđuje vrlo jasnu tendenciju postupnoga buđenja nacionalne svijesti i hrvatskoga identiteta u domaćim privrednim krugovima Bakra, Rijeke i Hrvatskog primorja, usred sve izrazitijih procesa postupne denacionalizacije, odnosno, mađarizacije i talijanizacije. Hrvatska se nova građanska svijest i samosvijest postupno razvijala kao oporba tim po vlastitu narodnost pogubnim procesima. Bila je to očito kolektivna svijest i samosvijest, koju je trebalo razvijati, oblikovati i jačati usporedno sa razvojem čitavoga društva, u vrlo osjetljivim i teškim političkim okolnostima, kada je vladala kulturna supremacija drugih jezika i kultura.

Prvi dioničar Franice i Medanićev ortak Josip Bakarčić Andrijin zvan Joško (1796.-1864.), rodom iz Drage, bio je riječki veletrgovac i brodovlasnik, jedan od najimućnijih i najutjecajnijih ljudi svoga vremena. Baveći se od mladosti trgovinom, razvio je veletrgovinu stokom te godinama opskrbljivao riječka i tršćanska tržišta. Nakon restauracije austrijske vlasti na području Rijeke i Hrvatskog primorja, uključuje se također u veletrgovinu žitom i drvom. Povezavrši se s brodovlasnicima iz Senja (Vranyczany), Kostrene (Medanić), Kraljevice (Tomac i Polić) i Mošćenica (Negovetić), postao je suvlasnik nekoliko jedrenjaka duge plovidbe, a nekoliko njih veće tonaže, dao je sagraditi na vlastiti račun. Prema podacima pomorskih statistika od 1850. do 1864. bio je vlasnik ili suvlasnik sedamnaest brodova duge plovidbe sa 9019 brt. Posjedovao je i šest velikih kuća i prostrana

${ }^{35}$ Narodne novine (Zagreb), XII., br. 77, subota, 26. rujna 1846. Hervatska i Slavonija. Dopis iz Bakra. Pretpostavljamo da bi autor ovoga članka mogao biti mladi Avelin Ćepulić. I. Lukežić, Neki podaci o djelatnosti riječkih brodograditelja iz 19. stoljeća. IV. Međunarodna konferencija o industrijskoj baštini, Rijeka 2010, str. 208-9.

36 Podaci su preuzeti iz suvremenih pomorskih godišnjaka (Annuario marittimo). 
zemljišta u Rijeci. Godine 1859. u ratnom je sukobu Austrije s Francuskom i Sardinijom, izgubio brik Maria Baccarcich. ${ }^{37}$

Zajedno s dr. Vatroslavom Vinkom Medanićem bio jedan od osnivača i dugogodišnji član uprave Narodne Čitaonice Riečke, a od 1850. obnašao je čast počasnoga vicekonzula Švedske i Norveške. Bio je nadležan za riječku luku i podvrgnut konzulatu u Trstu. Godine 1863. postaje članom riječkog gradskog zastupništva. Bio je dioničar Società Patriotica Fiumana (1843.) i peštanskog Ugarskog trgovačkog društva (1843.) Četrdesetih je godina bio poveo akciju da se podigne nova željeznička pruga od Vinkovaca do Rijeke, kako bi se Rijeka povezala sa kontinentalnim europskim tržištima. Kao veliki domoljub velikodušno je novčano podupirao mnoge značajne hrvatske ustanove. Godine 1849. uplatio je iznos od 5 forinti u korist glavnice Narodnog muzeja u Zagrebu. ${ }^{38}$ Te iste godine on i Medanić uplatili su po 50 forinti za ranjene i nemoćne vojnike u akciji prikupljanja dobrovoljnih novčanih prinosa koju je u Rijeci organizirao profesor Jakov A. Mikoč. ${ }^{39}$ Godine 1852. kod Banske vlade bio je upisao 20 akcija (dionica) za podizanje narodnoga kazališta u Zagrebu, u vrijednosti od 500 forinti. ${ }^{40}$ Bakarčić je u svibnju 1853. kao svoj dobrovoljni prinos u naravi za stradajuće žiteljstvo delničke podžupanije doprinio 10 vagana kukuruza. ${ }^{41}$ Umro je u veljači 1864, u šezdeset i osmoj godini života, od upale pluća. U trenutku smrti posjedovao je devet jedrenjaka duge plovidbe - brik, dvije nave i šest barkova. ${ }^{42} \mathrm{U}$ korist tadašnje Jugoslavenske akademije znanosti i umjetnosti u Zagrebu oporučno je darovao dvije tisuće forinti. ${ }^{43}$

Drugi Medanićev ortak i dioničar Franice bio je ugledni pomorski kapetan i imućni posjednik Anton Kopajtić (1799.-1871.), sin Tome Kopajtića Stjepanova, potjecao je iz ugledne bakarske obitelji čiji su se muški članovi tradicionalno bavili pomorstvom i kapetanskim pozivom. Bio je kapetan duge plovidbe, odnosno, zapovjednik trgovačkih brodova (capitaneus navalis

\footnotetext{
37 I. Lukežić, Povijest riječkih konzulata, Adamić, Rijeka 2004.

38 Narodne novine (Zagreb), 3. rujna 1849.

39 Bilo je prikupljeno 1084 forinti koje su bile proslijeđene banu Josipu Jelačiću, uz jedno popratno pismo. Narodne novine (Zagreb), 31. kolovoza 1849.

40 Narodne novine (Zagreb), XVIII, 11. veljače 1852.

41 Narodne novine (Zagreb), br. 120, 28. svibnja 1853. Popis.

42 R.F. Barbalić-I. Marendić, Onput kad smo partili. Zapisi o posljednjim kvarnerskim jedrenjacima, MH, Rijeka 2004, str. 5.
}

43 I. Lukežić, Povijest riječkih konzulata, Adamić, Rijeka 2004, str. 223-4. 
mercantilis), koji su u to vrijeme bili pretežno još pogonjeni vjetrom a ne parom. Prema podacima iz pomorskih godišnjaka stekao je zvanje kapetana duge plovidbe 1826. godine, na temelju potvrde koju mu je izdala nekadašnja mađarska vlada u Rijeci. ${ }^{44}$ Nakon toga započinje s aktivnom plovidbom kao zapovjednik na trgovačkim jedrenjacima duge plovidbe. U razdoblju od 1835. do 1845. godine kapetan Anton Kopajtić spominje se kao zapovjednik austrijskoga trgovačkoga brigantina Regolo, nosivosti 300 tona, koji je uglavnom prometovao između Odese, Carigrada i Trsta, Marseja, Carigrada i Trsta, te Trsta, Rijeke i Bakra, prevozeći različitu robu (žitarice, vino i dr.) na račun lokalnih trgovačkih tvrtki. Nakon Kopajtića jedrenjakom je zapovijedao kapetan A. Florio. Anton Kopajtić bio je otac znamenitoga brodovlasnika Sigismunda Kopajtića. ${ }^{45}$

Aktivniju ulogu u javnom i političkom životu Vinko Medanić započinje igrati od velikih previranja koja su zahvatila Rijeku tijekom burne 1848. i neposredno nakon toga, svrstavši se odlučno u tabor naprednih riječkih Hrvata i vatrenih domorodaca, među kojima je imao vrlo istaknutu poziciju, kao osoba od najvišega povjerenja slavnoga hrvatskog bana Josipa Jelačića. U pismu datiranom u Karlovcu 25. ožujka te godine Antun Vakanović, jedan od vođa hrvatskoga preporoda u Karlovcu, tadašnji prokurator primorski i prisjednik zemaljskoga suda u Rijeci, ovako izvještava svoga „,miloga pobratima” Ljudevita Gaja o tadašnjim riječkim događajima: „Ja sam se od 20-oga do danas na Fiumi i Verbovskom nahodio, danas pak simo došao, da čujem šta u Domovini biva, jer u Reku nikakvih privatnih glasovah nedobivamo. To je u sadašnje vreme veliki nedostatak, jer drugačie primorje, sasvim neshodnim i protivnim pravcom udariti moglo bi; čega se je s-tim više bojati, budući da u Reki velika politička živahnost vlada. - Za to bi trebalo svakidanje dopisivanje systematički uvesti; - Medanić bi morao dopisatelj biti; jer veliki popularitaet imade." ${ }^{46}$

Dana 22. svibnja 1848. ban Jelačić imenovao je komisiju koja je imala osigurati „mir i poredak u cijelom Primorju” protiv rovarenja mađarona. Članovi komisije bili su Ivan Mažuranić, koji je bio imenovan „za kotar

44 Annuario marittimo del Lloyd Austriaco, Trieste 1858, str. 249.

45 I. Lukežić, Sigismund pl. Kopajtić Bakarski - pomorski privrednik, domoljub i vizionar. Prilog poznavanju privredne elite sjeverozapadne Hrvatske, Bakarski zbornik, sv. 16, Bakar 2017, str. 7-182.

46 J. Horvat-J. Ravlić, Pisma Ljudevitu Gaju, Građa za povijest književnosti hrvatske, knjiga 26, JAZU, Zagreb 1956, str. 480. 
primorsko-komorski”, dr. Ignac Vinko Medanić za Rijeku (s kotarom) i Fran Kukuljević Sakcinski za Bakar (s kotarom). ${ }^{47}$ Zanimljivo je da su praške Národní noviny u to vrijeme najavile kako će kao poslanici/delegati na slavenski kongres u Pragu u svibnju te godine doći Vinko Medanić, Ivan Mažuranić, Dragojlo Kušlan i Josip Praus. ${ }^{48}$ Sredinom prosinca iste godine Medanić je na prijedlog banskoga povjerenika Josipa Bunjevca preuzeo na sebe novoustrojenu dužnost riječkoga nadziratelja sigurnosti. ${ }^{49}$

Dana 10. veljače 1849. banski namjesnik Mirko Lentulay obavještava bana Jelačića o otpuštenim riječkim činovnicima koji „biahu odalečeni po Vašem pověreniku od svojih službah kao ljuti nepriatelji roda našega, i potajni uzbuditelji neuka gradjanstva, proti obstojećem redu i političkom položaju". ${ }^{50}$ Bili su to Mađari Stjepan Privitzer, riječki vice-guverner, Mihajlo Horhy, gubernijalni prisjednik, Rudolf Farkaš, gubernijalni tajnik i Victoris, praktikant. Osim njih iz službe je bio otpušten dr. Jeronim Fabris, rodom Padovanac, dok se Josip Susanni, gubernijalni prisjednik, rodom iz Istre, sam odrekao službe. Po banskom povjereniku Josipu Bunjevcu, za prvoga gubernijalnog prisjednika imenovan je August Tosoni, kao tajnici uzeti su u službu Božo Pavletić i Žiga Farkaš, dok je za gubernijalnoga perovođu postavljen Gašpar Suzanić. Po Banskome vijeću za drugoga gubernijalnog prisjednika, odnosno prisjednika upraviteljstva imenovan je dr. Ignac Vinko Medanić. ${ }^{51}$ Krajem srpnja te godine Josip Bunjevac je na svoju ruku Medaniću ${ }^{52}$ prepustio i rukovođenje upravnih poslova u Primorju. ${ }^{53}$

47 J. Šidak, Studije iz hrvatske povijesti XIX. stoljeća, Sveučilište u Zagrebu-Institut za hrvatsku povijest, Zagreb 1973, str. 284.

48 J. Šidak, nav. dj., str. 284. Medanić i Mažuranić ipak nisu sudjelovali u radu Slavenskog kongresa u Pragu. Uz navedene Kušlana i Prausa, na Slavenskom kongresu su kao izaslanici Hrvatskog sabora sudjelovali Stanko Vraz i Maksimilijan Prica. Osim njih, na Kongresu je sudjelovalo još nekoliko hrvatskih političkih i kulturnih djelatnika. Bili su to: Andrija Torkvat Brlić, Mato Topalović, Vatroslav Lisinski i Franjo Tkalac. Milan Prelog, Slavenska renesansa 1780.-1848., Naklada Jugoslovenske štampe d.d., Zagreb, 1924., 324-327, 338340.

49 Narodne novine (Zagreb), br. 138, 12. XII. 1848.

50 T. Markus, Korespondencija bana Jelačića i Banskog vijeća, Hrvatski institut za povijest, Dom i svijet, Zagreb 1998, str. 149.

51 T. Markus, nav. dj., str. 149.

52 Privremeno, jer se iz dopisa može razabrati da je ta mjera bila na snazi za vrijeme Bunjevčeve odsutnosti iz Rijeke.

53 T. Markus, nav. dj., str. 264. 
Krajem srpnja 1849. godine ban Josip Jelačić povjerio je Ignacu Vinku Medaniću, premda je bio slabo poznat široj javnosti, da kao jedan od devetorice ljudi iz Banske Hrvatske bude član povjerenstva koje je u Beču, nakon proglašenja Oktroiranoga ustava, trebalo sudjelovati u „ustrojenju naše domovine" ${ }^{54}$ Ovo povjerenstvo trebalo je obaviti pregovore s bečkom vladom o zaključcima Sabora $1848 .{ }^{55}$ Tako je početkom kolovoza te godine doputovao iz Rijeke u Beč te zajedno sa svojom suprugom odsjeo u svratištu Kaiserin von Oesterreich. ${ }^{56}$ Iste godine bio je član odbora za izradu pravila Narodnog hervatskog družtva na poziv banskoga povjerenika Josipa Bunjevca, u kojem su još bili Antun Vakanović, Faustin Suppè, Božo Pavletić, Petar Dabala i Šišman Farkaš, dok je perovođa bio Gašpar Susanić. Odmah prvoga dana u to se društvo upisalo sedamdeset članova. Bio je to početak djelovanja buduće Narodne čitaonice riečke, u kojoj je Medanić obnašao i čast člana prvoga upravnog odbora i prvoga podpredsjednika toga hrvatskog domoljubnog udruženja. ${ }^{57}$ Godine 1850. na prijedlog Hrvatsko-slavonske komisije za uvođenje sudova imenovalo ga je c. kr. ministarstvo pravosuđa kao advokata i prisjednika riječke gubernije za člana/prisjednika riječkoga zemaljskog suda. ${ }^{58}$ Medanić je bio povjerenik hrvatske vlade i prilikom osnivanja Trgovačko-industrijske komore u Rijeci. ${ }^{59}$ Kada je 1851. među riječkim odvjetnicima došlo do velikoga razmimoilaženja oko konačnoga prihvaćanja hrvatskoga kao glavnoga službenog jezika u sudovanju i gradskoj upravi, Medanić je, uz Faustina Suppèa, nije želio prihvatiti memorandum dvanaestorice riječkih odvjetnika što se zauzimao za talijanski kao uredovni jezik, već je ponosno ostao privržen svome hrvatskom jeziku. ${ }^{60}$

54 Narodne novine (Zagreb), XV, br. 106, 2. kolovoza 1849. Uz Medanića, članovi tog banskoga vijeća, bili su od strane Hrvatske kanonik Stjepan Mojzes, vlastelin Donat Tomić, savjetnik Franjo Novak, predsjednik sudbenog stola Herman Bužan i Ivan Mažuranić, dok su predstavnici Slavonije bili veliki požeški župan Julije Janković, virovitički podžupan Josip Janković, te podžupan srijemski Trifun Mladenović. Oni nisu reprezentirali javno mnijenje i politiku u Hrvatskoj jer su, poput Medanića, bili javnosti uglavnom nepoznati. T. Markus, Korespondencija bana Jelačića i Banskog vijeća, Hrvatski intistut za povijest, Dom i svijet, Zagreb 1998, str. 34.

55 Jelačić je spis o imenovanju Medanića članom povjerenstva za pregovore s bečkom vladom potpisao u Rumi, 25. srpnja 1849. godine. T. Markus, nav. dj., str. 266-267.

56 Fremden-Blatt Wien (Beč), br. 186, 7. kolovoza 1849.

57 Spomen-knjiga Narodne Čitaonice Riečke, Sušak 1901.

58 Narodne novine (Zagreb), br. 154, 8. VII. 1850. Zvanična čast.

59 Narodne novine (Zagreb), XVIII, 24. I. 1852.

60 I. Lukežić, Riječki kvartet, Biblioteka časopisa Fluminensia, Rijeka 2008, str. 35. 
Obavljao je Medanić neko vrijeme dužnost pisara konzulata Papinske Države u Rijeci. Bio je sanitetski inspektor pri riječkome Magistratu i član Gospodarskoga društva iz Zagreba. ${ }^{61}$ Svojim je novčanim sredstvima rado i izdašno podupirao različite značajne narodne projekte i inicijative. Godine 1850. dao je dobrovoljni doprinos od 9 fjorina i 35 krajcara za nabavku rijetkih fizikalnih instrumenata Narodnoga muzeja u Zagrebu, 1851. godine 3 forinte za podignuće spomenika hrvatskome pjesniku Stanku Vrazu, 1 forintu na fizikalni atlas dr. Beghausa ${ }^{62}$ za Narodni muzej, te 5 forinta za potporu žitelja grada Varaždina i obližnjih sela koji su zahvaćeni poplavama $^{63}$, godine 1852 . otkupljuje deset akcija u vrijednosti od 250 forinta za podizanje narodnoga kazališta u Zagrebu ${ }^{64}$, godine 1853. daruje 5 forinta za stradajuće žiteljstvo delničke podžupanije ${ }^{65}$, a 1855. kod gradskoga magistrata u Rijeci priložio je 5 forinta za građenje Votivne crkve u Beču „kao uspomenu sretnoga izbavljenja njeg. c. k. apost. Veličanstva”. ${ }^{66}$ Bio je redoviti član Kukuljevićeva Društva za povjesnicu jugoslavensku. ${ }^{67}$

Početkom pedesetih godina riječki Hrvati, okupljeni u tadašnjoj Narodnoj čitaonici, osnovali su poseban Odbor za podignuće spomenika na Grobničkom polju. Na čelu toga odbora bili su Ivan Nepomuk Durbešić, trgovac i posjednik u Čavlima, kasniji predsjednik Čitaonice, Šišman Farkaš Vukotinović, državni činovnik i tadašnji predsjednik Čitaonice, Dragutin Šporer, trgovac, brat književnika i liječnika dr. Jurja Matije Šporera, posjednik Josip Perušić, riječki odvjetnici Faustin Suppè i dr. Vinko Ignac Medanić, Matija Bartolić i mnogi drugi mjesni uglednici. Kada su išli razgledati prikladno mjesto na Grobničkome polju, da se podigne spomenik, bilo ih je u tom društvu više od trideset osoba „svi vatreni domorodci”, i onaj dan ih je počastio g. Durbešić „baš prijateljskom objedom”. ${ }^{68}$

61 Narodni dom. Gospodarsko društvo. Narodne novine (Zagreb), br. 185, 12. VIII. 1851. Za godinu 1851. priložio je bio na ime članarine iznos od 4 forinta.

62 Narodne novine (Zagreb), br. 166, 21. VII. 1851. Museum.

63 Narodne novine (Zagreb), br. 265, 18. studenog 1851.

64 Narodne novine (Zagreb), 22. srpnja 1850, 21. kolovoza 1851., 2. travnja 1852.

65 Narodne novine (Zagreb), br. 120, 28. svibnja 1853. Popis dobrovoljnih prinesakah do sada u gradu Rieki sakupljenih za stradajuće žiteljstvo c. kr. podžupanie delničke.

66 Narodne novine (Zagreb), br. 13, 17. siječnja 1855. Zvanično.

67 U tu svrhu uplatio je dvije forinte srebra. Narodne novine (Zagreb), 19. veljače 1852.

68 Primorac (Kraljevica), br. 98, 16. studenog 1875. Prinesci za spomenik na grobničkom polju. 
Početkom kolovoza 1853. putovao je iz Trsta preko Ljubljane u Zagreb, gdje je koncem srpnja iste godine bio odsjeo u gostionici „zum Kaiser von Oesterreich". ${ }^{69}$ Koncem svibnja 1854. bio je opet u Ljubljani, na putu od Varaždina do Rijeke. ${ }^{70}$ U travnju 1855. doputovao je iz Karlovca u Zagreb, smjestivši se u svratištu „Kod krune” (Krone). ${ }^{71}$ Danas sa sigurnošću ne znamo koja je bila svrha tih putovanja. Budući da je bio imućan građanin, vjerojatno ih je poduzimao u neke privatne svrhe. Dana 6. rujna 1855. godine uputio je Medanić svome prijatelju Ivanu Kukuljeviću Kukuljeviću pismo iz Rijeke u kome ga moli za posredovanje da se njegovu sinu Rimku omogući ishodovanje putovnice za Rusiju, kako bi mogao studirati na moskovskome sveučilištu. ${ }^{72}$

Na kraju se može zaključiti kako je dr. Ignac (Vatroslav) Vinko Medanić (1805.-1856.), bio istaknuti riječki odvjetnik, posjednik i brodovlasnik, patricijski vijećnik Bakra i Rijeke. Po očevoj je strani potjecao iz Kostrene Sv. Barbare. Riječ o neobično značajnom riječkom građaninu svoga vremena, danas nažalost zaboravljenom, koji se istaknuo na mnogim područjima, od gospodarstva, preko kulture i javnoga života, do politike, tako da je ostavio značajan trag u svome vremenu. Pokrenuo je mnoge važne inicijative, posebno se ističući kao veliki riječki i hrvatski domoljub, te pobornik ideja slavenske uzajamnosti. Bio je znanac hrvatskoga pravopisnoga reformatora Josipa Završnika, slovačkoga preporoditelja Jana Kollára, vođe ilirskoga pokreta Ljudevita Gaja, bana Josipa Jelačića Bužimskoga, hrvatskoga polihistora Ivana Kukuljevića Sakcinskog i drugih znamenitih osoba svoga vremena. Bio je prvi potpredsjednik Narodne čitaonice riečke i glavni vladin povjerenik za osnivanje Gospodarske komore u Rijeci.

\section{Arhivska građa}

Državni arhiv u Rijeci, PR-1, kut. 326.

Državni arhiv u Varaždinu. Korespondencija Ivana Kukuljevića. Pismo od 5. rujna 1855 . godine.

69 Laibacher Zeitung (Ljubljana), br. 173, 2. kolovoza 1853. Agramer Zeitung, br. 173, 30. srpnja 1853.

70 Laibacher Zeitung (Ljubljana), br. 119, 21. svibnja 1854.

71 Agramer Zeitung (Zagreb), br. 79, 5. travnja 1855.

72 Državni arhiv u Varaždinu. Korespondencija Ivana Kukuljevića. Pismo od 5. rujna 1855. godine. 


\section{Izvori i literatura}

Ad Ignazio Medanich quando sacramento di coniugale fede solemente proferiva a Francesca Zaccaria giovane che il terzo lustro appena ha fecco nobile ingenua virtuosa a tutti cara per la bontà del cuore per la dolcezza dei modi G. dott. S. quale arra di veri e saltava questi versi dedicano, Fiume 1843. Tipografia fratelli Karletzky.

Barbalić, Radojica F. - Marendić, Ivo (2004) Onput kad smo partili. Zapisi o posljednjim kvarnerskim jedrenjacima, $\mathrm{MH}$, Rijeka.

Fontes rerum hungaricarum. Magyar törtenélmi fórrasok: MATRICULA ED AETA HUNGARORUM IN UNIVERSITATIBUS ITALIAE STUDENTUM, vol. I, PADOVA 1264-1864, Budapest 1915.

Horvat, Josip - Ravlić, Jakša (1956) Pisma Ljudevitu Gaju, Građa za povijest književnosti hrvatske, knjiga 26, JAZU, Zagreb.

Horvat, Josip (1975) Ljudevit Gaj, SNL, Zagreb.

Klen, Danilo (1986) Gospodarske prilike u Rijeci od 1813. do 1848. do ponovne austrijske okupacije do Bunjevčeva zauzeća, u: Rad JAZU, knj. 417, Zagreb.

Lukežić, Irvin (1994) Grobnički biografski leksikon, Libellus, Rijeka - Crikvenica.

Lukežić, Irvin (2004) Povijest riječkih konzulata, Adamić, Rijeka.

Lukežić, Irvin (2004) Riječke glose, ICR, Rijeka.

Lukežić, Irvin (2006) Ogledalo bašćinsko, ICR, Rijeka.

Lukežić, Irvin (2008) Riječki kvartet, Biblioteka Fluminensia, FF, Rijeka.

Lukežić, Irvin (2010) Neki podaci o djelatnosti riječkih brodograditelja iz 19. stoljeća. IV. Međunarodna konferencija o industrijskoj baštini, Rijeka.

Lukežić, Irvin (2017) Sigismund pl. Kopajtić Bakarski - pomorski privrednik, domoljub i vizionar. Prilog poznavanju privredne elite sjeverozapadne hrvatske, Bakarski zbornik, sv. 16, Bakar, str. 7-182.

Markus, Tomislav (1998) Korespondencija bana Jelačića i Banskog vijeća, Hrvatski institut za povijest, Dom i svijet, Zagreb.

Stulli, Bernard (1975) Prijedlozi i projekti željezničkih pruga u Hrvatskoj 18251863, knj. I., Institut za hrvatsku povijest, Zagreb 1975.

Šidak, Jaroslav (1973) Studije iz hrvatske povijesti XIX. stoljeća, Sveučilište u Zagrebu -Institut za hrvatsku povijest, Zagreb. 


\section{Periodika}

Agramer Zeitung (Zagreb), br. 173, 30. srpnja 1853.

Agramer Zeitung (Zagreb), br. 79, 5. travnja 1855.

Annuario marittimo del Lloyd Austriaco, Trieste 1858.

Fremden-Blatt Wien (Beč), br. 186, 7. kolovoza 1849.

Fremden-Blatt (Beč), br. 217, 12. rujna 1851.

Ilirske Narodne novine (Zagreb), VIII, br. 78, 28. rujna 1842. Horvatska i Slavonia.

Laibacher Zeitung (Ljubljana), br. 69, 27. kolovoza 1844.

Laibacher Zeitung (Ljubljana), br. 85, 22. listopada 1844.

Laibacher Zeitung (Ljugljana), br. 55, 12. srpnja 1845.

Laibacher Zeitung (Ljubljana), br. 173, 2. kolovoza 1853.

Laibacher Zeitung (Ljubljana), br. 119, 21. svibnja 1854.

La Voce del popolo (Rijeka), 1902. Ifigenia ved. Corossacz nata Medanich (nekrolog).

Narodne novine (Zagreb), XII., br. 77, subota, 26. rujna 1846. Hervatska i Slavonija. Dopis iz Bakra.

Narodne novine (Zagreb), br. 138, 12. prosinca 1848.

Narodne novine (Zagreb), XV, br. 106, 2. kolovoza 1849.

Narodne novine (Zagreb), 3. rujna 1849.

Narodne novine (Zagreb), 31. kolovoza 1849.

Narodne novine (Zagreb), br. 154, 8. srpnja 1850. Zvanična čast.

Narodne novine (Zagreb), 22. srpnja 1850

Narodne novine (Zagreb), br. 185, 12. kolovoza 1851. Narodni dom. Gospodarsko društvo.

Narodne novine (Zagreb), br. 166, 21. srpnja 1851. Museum.

Narodne novine (Zagreb), 21. kolovoza 1851.

Narodne novine (Zagreb), br. 265, 18. studenoga 1851.

Narodne novine (Zagreb), XVIII, 24. siječnja 1852.

Narodne novine (Zagreb), XVIII, 11. veljače 1852.

Narodne novine (Zagreb), 19. veljače 1852.

Narodne novine (Zagreb), 2. travnja 1852. 
Narodne novine (Zagreb), br. 120, 28. svibnja 1853. Popis.

Narodne novine (Zagreb), br. 13, 17. siječnja 1855. Zvanično.

Narodne novine (Zagreb), br. 183, 8. kolovoza 1856. Neuredovni dio. Austrianska carevina. Zagreb, 8. kolovoza.

Primorac (Kraljevica), br. 98, 16. studenog 1875. Prinesci za spomenik na Grobničkom polju.

Rijeka 1841. iz pera Jana Kollára, Dometi, god. 22 (1989), br. 4.

Scematismo dell 'imperiale Regio Litorale austriaco-illirico, Trieste 1831.

Scematsmo Del Littorale Ungarico, Fiume 1838.

\section{SUMMARY \\ Irvin Lukežić \\ DR. VATROSLAV VINKO MEDANIĆ - A PROMINENT RIJEKA ATTORNEY, SUPPORTER OF THE CROATIAN NATIONAL MOVEMENT (ILLIRISM) AND THE IDEA OF SLAVIC BROTHERHOOD}

The topic of this article is related to Rijeka at the time of the infamous Bach's absolutism, when the Narodna Čitaonica Riečka (Croatian Popular Lecture Club of Rijeka) began to operate. Dr. Ignac (Vatroslav) Vinko Medanić (1805-1856), a prominent Rijeka attorney, landlord and shipowner, patrician councillor of Bakar and Rijeka, played an important role in its foundation. This contribution is about an unusually important citizen of Rijeka of his time, who is today unfortunately forgotten. He was an acquaintance of the Croatian orthographic reformer Josip Završnik, of the Slovak revivalist and writer Jan Kollár, of the leader of the Illyrian movement Ljudevit Gaj, the Ban and Governor of Rijeka Josip Jelačić Bužimski, of the Croatian polyhistor and writer Ivan Kukuljević Sakcinski and other distinguished persons of his time. He was the first vice-president of the Narodna Čitaonica Riečka and the chief government commissioner for the founding of the Chamber of Commerce in Rijeka. In this paper we focus on the most important biographic details of his career and the main characteristics of his activist work, especially of his work in the domain of public education and culture.

Keywords: Rijeka; $19^{\text {th }}$ century; Croatian culture; Medanić; Illyrian movement; Slavic movement 